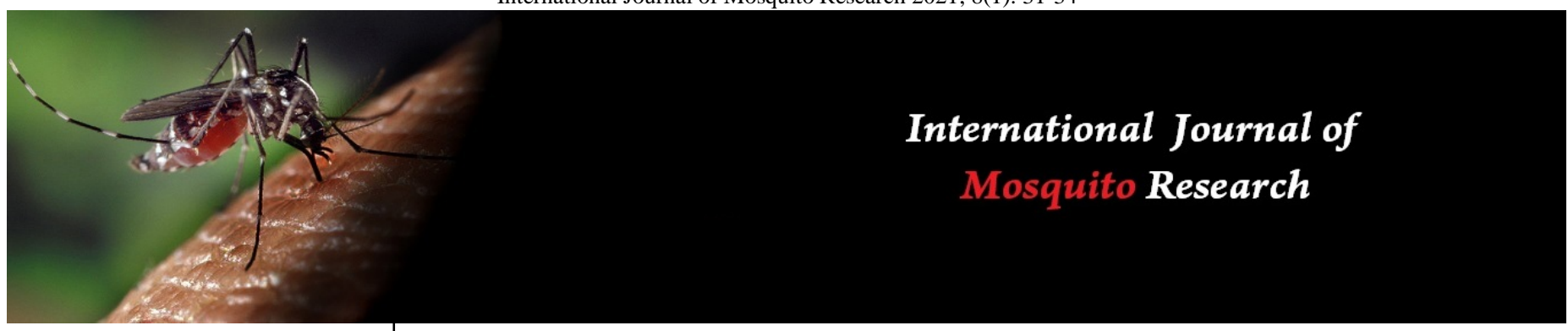

ISSN: 2348-5906

CODEN: IJMRK2

IJMR 2021; 8(1): 31-34

(C) 2021 IJMR

Received: 18-10-2020

Accepted: 16-12-2020

\section{Dipika Doloi}

Research Scholar, Department of Zoology, Cotton University,

Guwahati, Assam, India
Corresponding Author: Dipika Doloi

Research Scholar, Department of Zoology, Cotton University,

Guwahati, Assam, India

\section{A study on certain biological control methods to control and manage vector-borne diseases}

\section{Dipika Doloi}

DOI: https://doi.org/10.22271/23487941.2021.v8.i1a.497

\begin{abstract}
Vector-borne diseases are the diseases which are caused by pathogens, i.e., parasites, viruses and bacteria that are transmitted by vectors, such as, mosquitoes, snails, blackflies, sandflies, fleas, lice, tsetse flies, ticks, bugs, etc. It becomes essential to control the vector so as to cut off or limit the transmission of pathogens by reducing or elimination the human contact with the vector. Use of chemical control methods results in accumulation of insecticides in the food chain, moreover, the vector may become resistant to the insecticides. Therefore, biological control methods should be employed as they are safe, environment friendly, sustainable, targets the mosquito species and reduces the use of insecticides. Biological control methods attempt to utilize the natural enemies of mosquitoes at different stages of life cycle, both as predators and parasites. Mosquitoes are responsible for transmitting several diseases, including malaria, dengue, chikungunya, Zika, filariasis, yellow fever, etc. This review study presents an overview of vectors, vector-borne diseases and certain biological control methods with reference to mosquito-borne diseases.
\end{abstract}

Keywords: Biological, malaria, mosquito-borne diseases, vector

\section{Introduction}

Mosquitoes are responsible for transmitting several diseases, including malaria, dengue, chikungunya, Zika, filariasis, yellow fever, etc. One of the most common vector-borne diseases prevalent in tropical and subtropical areas of the world, including regions in Africa, Asia and America is Malaria ${ }^{[24]}$. Therefore, it becomes very much important to control the vector so as to limit the transmission of pathogens by reducing or elimination the human contact with the vector. Use of chemical control methods, i.e., use of chemical insecticides against the mosquito vectors, results the mosquitoes to become resistant to insecticides. Though insecticides controls the mosquito vectors, but acts as poisoning risks to non-target organisms and also gets accumulated in the food chain, which contaminate the food chain and cause serious health hazards, which results in physiological resistances to the vector species and consequently leads to failure of vector control methods and cause harmful effects on nontarget animals ${ }^{[7]}$. Continuous usage of biological control agents has showed minimal sideeffects on humans, domestic creatures and on wildlife ${ }^{[13]}$. Moreover, biological control methods are sustainable and targets the mosquito species and reduces the use of insecticides. Therefore, this review study deals with an overview of vectors, diseases transmitted by the vectors and certain biological control methods with reference to mosquito-borne diseases.

\section{Vector and Vector-borne diseases}

Vectors are living organisms that has the capacity to transmit infectious pathogens or diseases between humans, or from animals to humans. A vector does not cause disease itself but spread infection by conveying pathogen from one host to another. Many of these vectors are bloodsucking insects, which ingest disease-producing microorganisms during a blood meal from an infected host (human or animal) and later transmit it into a new host by mechanical transmission or by biting while feeding the blood from host body, after the pathogen undergoes multiplication. Vector-borne diseases are the diseases which are caused by pathogens, i.e., parasites, viruses and bacteria that are transmitted by vectors, such as, mosquitoes, snails, blackflies, sandflies, fleas, lice, tsetse flies, ticks, bugs, etc. 
Dengue, Chagas disease, Japanese encephalitis, leishmaniasis, lymphatic filariasis, malaria, and yellow fever threatens over $80 \%$ of the world's population and disproportionately affect the poorest populations living in the tropics and subtropics ${ }^{[6]}$. Distribution of vector-borne diseases is determined by a complex set of demographic, environmental and social factors.

\subsection{Transmission}

There are number of insects which transmits the germs of different diseases in the human beings mechanically, i.e., they act as mechanical vectors. Mechanical vectors transmits the pathogens by transporting the causative agent from contaminated material on their feet or mouth parts and then spreading the pathogens or parasites on to human food, drink, faces or eyes. The other type is biological vector. In case of biological vectors, the pathogen in the infested host, are ingested by the vector where they undergo cyclical changes and also undergoes multiplication in order to mature to an infective stage and has the capacity to transmit the parasite to humans or animal host when the vector takes a blood meal through biting. This usually takes several days before they are capable of being transmitted to a new host.

Table 1: Table showing list of some of the vector-borne diseases, their vector and types of pathogen ${ }^{[19,23]}$

\begin{tabular}{|c|c|c|}
\hline Vector & Diseases & Pathogen \\
\hline Aedes mosquitoes & $\begin{array}{c}\text { Chikungunya } \\
\text { Dengue } \\
\text { Lymphatic filariasis } \\
\text { Rift Valley fever } \\
\text { Yellow Fever } \\
\text { Zika }\end{array}$ & $\begin{array}{l}\text { Virus } \\
\text { Virus } \\
\text { Parasite } \\
\text { Virus } \\
\text { Virus } \\
\text { Virus }\end{array}$ \\
\hline Anopheles mosquitoes & $\begin{array}{l}\text { Lymphatic filariasis } \\
\text { Malaria }\end{array}$ & $\begin{array}{l}\text { Parasite } \\
\text { Parasite }\end{array}$ \\
\hline Culex mosquitoes & $\begin{array}{c}\text { Japanese encephalitis } \\
\text { Lymphatic filariasis } \\
\text { West Nile fever }\end{array}$ & $\begin{array}{c}\text { Virus } \\
\text { Parasite } \\
\text { Virus } \\
\end{array}$ \\
\hline Blackflies & Onchocerciasis (river blindness) & Parasite \\
\hline Fleas & $\begin{array}{c}\text { Plague (transmitted from rats to humans) } \\
\text { Tungiasis }\end{array}$ & $\begin{array}{c}\text { Bacteria } \\
\text { Ectoparasite }\end{array}$ \\
\hline Lice & $\begin{array}{c}\text { Typhus } \\
\text { Louse-borne relapsing fever }\end{array}$ & $\begin{array}{l}\text { Bacteria } \\
\text { Bacteria }\end{array}$ \\
\hline Sandflies & $\begin{array}{c}\text { Leishmaniasis } \\
\text { Sandfly fever (Phlebotomus fever) }\end{array}$ & $\begin{array}{l}\text { Parasite } \\
\text { Virus }\end{array}$ \\
\hline Ticks & $\begin{array}{c}\text { Crimean-Congo haemorrhagic fever } \\
\text { Lyme disease } \\
\text { Relapsing fever (borreliosis) } \\
\text { Rickettsial diseases } \\
\text { Tick-borne encephalitis } \\
\text { Tularaemia }\end{array}$ & $\begin{array}{l}\text { Virus } \\
\text { Bacteria } \\
\text { Bacteria } \\
\text { Bacteria } \\
\text { Virus } \\
\text { Bacteria }\end{array}$ \\
\hline $\begin{array}{l}\text { Blood-sucking reduviid bugs (mainly } \\
\text { Triatoma, Panstrongylus and Rhodnius) }\end{array}$ & Chagas disease (American trypanosomiasis) & Parasite \\
\hline Tsetse flies & Sleeping sickness (African trypanosomiasis) & Parasite \\
\hline
\end{tabular}

\section{Certain Biological Control Methods}

Biological control methods or strategies against the vectors are safe and environmental-friendly. Vector control is an essential component of mosquito-borne disease prevention and control, in which, targeting the mosquito vectors becomes the key control strategy against major mosquito- borne diseases. Its aim is to interrupt or eliminate local transmission or reduce vulnerability to disease and prevent secondary infections from introduced diseases and prevent outbreaks ${ }^{[12]}$. Although use of insecticides in controlling the vectors have been successful, current ecological and environmental protection standards make insecticide-based strategies unsustainable and due to the adverse effects of many insecticides on the non-target species, their environmental impact, the contamination of soil and water and the development of selective processes, and subsequently the mosquitoes becomes resistance to insecticides ${ }^{[22]}$. Therefore, to manage the mosquito populations, biological control methods can be used, which uses natural enemies. There are several types of biological control like the direct introduction of parasites, pathogens and predators to target mosquitoes.

Predatory fishes feeding on the mosquito larvae are used to control vector diseases. These predatory fishes feed on mosquito larvae as a preventative biological control agent against mosquitoes to reduce mosquito larvae from a water source. Among all the bio-control agents, use of larvivorous fishes are the most efficient method in controlling mosquito larvae all over the world, since the early- 1900s, which was

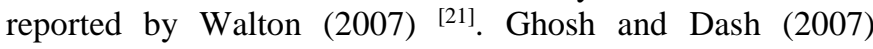
reported about 315 fish species under seven genera having larvivorous property could be used as larvivorous fish in controlling malaria ${ }^{[5]}$. Ramarao (2014) reported 58 species of larvivorous fish from the lower Manair Dam at Karimnagar, Andhra Pradesh ${ }^{[14]}$. Rao et al. (2015) reported about 22 species of larvivorous fish from Kolleru Lake of Andhra Pradesh ${ }^{[15]}$. Similarly, 29 species of larvivorous fish from six orders, 14 families and 20 genera were reported from Kolleru by Krishna et al. (2016) ${ }^{[11]}$. Das et al. (2018) ${ }^{[3]}$ studied and reported the potential larvivorous fish species on the basis of their larvivorous efficacy and extensive distribution. Highlevel of larvivorous potentiality of the larvivorous fish species was found in the different areas of Ranchi district in Jharkhand, which were utilized for controlling the mosquito larval populations. They also reported that those native 
larvivorous fishes could be used in the integrated mosquito control programmes ${ }^{[3]}$. The carnivorous fishes like Gambusia are now introduced in the mosquito breeding places at various places in India, which feeds on the mosquito larvae voraciously. However, the introduction of Gambusia in certain habitats, resulted in the elimination of many native fish species from these habitats ${ }^{[16]}$.

Dragonfly nymphs are used to control the growing population of mosquitoes. Among the various biological control agents, predatory insects like damselfly and dragonfly nymphs have gained a high consideration as significant predators of the larvae of Aedes mosquitoes [20]. Samanmali et al. (2018), reported that Anax indicus, Pantala flavescens, Gynacantha dravida, Orthetrum sabina sabina, and Tholymis tillarga are active feeders and consumes the Aedes aegypti mosquito larvae in notable quantities under laboratory conditions ${ }^{[17]}$.

Bacillus thuringiensis strain also proved much competent in controlling Aedes mosquito. Bacillus thuringiensis (Bti) and Bacillus sphaericus (Bs) are bacterial larvicidal strains which are used in controlling malaria vector ${ }^{[1]}$. The toxicity of Bti and $B$ s mainly resides in the production of endotoxin proteins that destroy the larval stomach and cause death of the vector [4].

The use of Wolbachia wMelPop bacterial strain can be a start for an innovative biological approach to control mosquitoborne diseases. Bacteria of the genus Wolbachia are Gramnegative and are found in the cytoplasmic vacuoles inside the cells of their insects, isopods, mites, arachnids and nematodes hosts ${ }^{[9]}$. Moreover, this intracellular bacteria such as Wolbachia can be used to manipulate their host biology, including the immune system, and regarded as innovative biocontrol approach to control insect-transmitted diseases. Many studies attempted to show the potential for Wolbachia to be used in such a strategy to control mosquito-transmitted diseases ${ }^{[2]}$. Wolbachia has many other characteristics, like the capacity to perturb insect ecology, behaviour, and physiology, making it to be the best for blocking or at least significantly reducing the transmission of pathogens of medical importance, which are reported by Shaw et al. (2016) ${ }^{[18]}$. When this Wolbachia wMelPop bacterial strain is introduced into Aedes aegypti, it resulted in an up regulation of the mosquito immunity and reduced its life span, moreover, inhibiting the development of filarial nematodes in these mosquitoes ${ }^{[10]}$. The somatic infection of Anopheles gambiae with two Wolbachia strains (wMelPop and wAlbB) significantly inhibited Plasmodium falciparum oocyst levels in the mosquito midgut ${ }^{[8]}$. These agents either directly target the vector or halts/ stops the development of the parasite within the mosquito, thereby, helping to eradicate malaria.

\section{Conclusion}

Mosquitoes are important vectors of diseases, especially in the tropical and sub-tropical areas of the world. As use of chemical control methods, i.e., insecticides results in resistance of the vectors to insecticides, moreover, it gets accumulated in the food chain, which is a growing problem; therefore attention should be given to other control methods. Among the control methods available for use against mosquito larvae, biological control may be advantageous, as because they are safe, environment friendly, sustainable, targets the mosquito species and thereby reduces the use of chemical insecticides.

\section{References}

1. Barbazan P, Baldet T, Darriet F, Escaffre H, Djoda DH, Hougard JM. Control of Culex quinquefasciatus (Diptera: Culicidae) with Bacillus sphaericus in Maroua, Cameroon. Journal of the American Mosquito Control Association 1997;13(3):263-269.

2. Bian G, Joshi D, Dong Y, Lu P, Zhou G, Pan X et al. Wolbachia invades Anopheles stephensi populations and induces refractoriness to Plasmodium infection. Science. 2013;340(6133):748-751.

3. Das MK, Rao MR, Kulsreshtha AK. Native larvivorous fish diversity as a biological control agent against mosquito larvae in an endemic malarious region of Ranchi district in Jharkhand, India. Journal of vector borne diseases 2018;55(1):34-41.

4. Federici BA, Park HW, Bideshi DK, Wirth MC, Johnson JJ, Sakano Y et al. Developing recombinant bacteria for control of mosquito larvae. Journal of the American Mosquito Control Association 2007;23(2):164-175.

5. Ghosh SK, Dash AP. Larvivorous fish against malaria vectors: a new outlook. Transactions of the Royal Society of Tropical Medicine and Hygiene 2007;101(11):10631064.

6. Golding N, Wilson AL, Moyes CL, Cano J, Pigott DM, Velayudhan $\mathrm{R}$ et al. Integrating vector control across diseases. BMC Medicine 2015;13(1):1-6.

7. Gupta S, Banerjee S. Comparative assessment of mosquito biocontrol efficiency between guppy (Poecilia reticulata) and Panchax minnow (Aplocheilus panchax). Bioscience Discovery 2013;4(1):89-95.

8. Hughes GL, Koga R, Xue P, Fukatsu T, Rasgon JL. Wolbachia infections are virulent and inhibit the human malaria parasite Plasmodium falciparum in Anopheles gambiae. PLoS Pathogens 2011;7(5):1-8.

9. Ilinsky Y, Kosterin OE. Molecular diversity of Wolbachia in Lepidoptera: Prevalent allelic content and high recombination of MLST genes. Molecular Phylogenetics and Evolution 2017;109:164-179.

10. Kambris Z, Cook PE, Phuc HK, Sinkins SP. Immune activation by life-shortening Wolbachia and reduced filarial competence in mosquitoes. Science. 2009;326(5949):134-136.

11. Krishna CH, Rao JC, Veeraiah K. Diversity of larvivorous fish fauna in Lake Kolleru (AP), India. International Journal of Fauna and Biological Studies. 2016;3(3):24-28.

12. Niang EH, Bassene H, Fenollar F, Mediannikov O. Biological control of mosquito- borne diseases: the potential of Wolbachia-based interventions in an IVM framework. Journal of Tropical Medicine. 2018, 1-15.

13. Raghavendra K, Subbarao SK. Chemical insecticides in malaria vector control in India. ICMR Bull 2002;32(10):93-99.

14. Rama Rao K. A study on larvivorous fish species efficacy of lower Manair dam at Karimnagar, Andhra Pradesh, India. Pelagia Research Library. Advances in Applied Science Research 2014;5(2):133-143.

15. Rao JC, Rao KG, Raju CS, Simhachalam G. Larvicidal efficacy of four indigenous ornamental fish species of lake Kolleru, India. Journal of Biodiversity and Environmental Sciences 2015;7(1):164-172.

16. Rupp HR. Adverse assessments of Gambusia affinis: an alternate view for mosquito control practitioners. Journal 
of the American Mosquito Control Association 1996;12(2):155-159.

17. Samanmali C, Udayanga L, Ranathunge T, Perera SJ, Hapugoda M, Weliwitiya C. Larvicidal potential of five selected dragonfly nymphs in Sri Lanka over Aedes aegypti (Linnaeus) larvae under laboratory settings. BioMed research international. 2018;1-10.

18. Shaw WR, Marcenac P, Childs LM, Buckee CO, Baldini F, Sawadogo SP et al. Wolbachia infections in natural Anopheles populations affect egg laying and negatively correlate with Plasmodium development. Nature communications 2016;7(1):1-7.

19. Tembhare DB. Pests of Medical Importance. In Modern Entomology. 2nd ed., Himalaya Publishing House, Mumbai, 2016, 389-397.

20. Venkatesh A, Tyagi BK. Predatory potential of Bradinopyga geminata and Ceriagrion coromandelianum larvae on dengue vector Aedes aegypti under controlled conditions (Anisoptera: Libellulidae; Zygoptera: Coenagrionidae; Diptera: Culicidae). Odonatologica 2013;42(2):139-149.

21. Walton WE. Larvivorous fish including Gambusia. Journal of the American Mosquito Control Association. 2007;23(2):184-220.

22. Wilke AB, Marrelli MT. Paratransgenesis: A promising new strategy for mosquito vector control. Parasites \& vectors. 2015;8(1):1-9.

23. Wilson AL, Courtenay O, Kelly-Hope LA, Scott TW, Takken W, Torr SJ, Lindsay SW. The importance of vector control for the control and elimination of vectorborne diseases. PLoS neglected tropical diseases. 2020;14(1): e0007831.

24. World Health Organization Regional Office for SouthEast Asia. Anopheline Species Complexes in South and South-East. Vol. 57. World Health Organization Regional Office for South-East Asia, New Delhi, India 2007, 1102. 